\title{
MECHANISMS IN ENDOCRINOLOGY Vitamin D and COVID-19
}

\author{
John P Bilezikian 1 1, Daniel Bikle ${ }^{2}$, Martin Hewison ${ }^{3}$, Marise Lazaretti-Castro4, Anna Maria Formenti ${ }^{5}$, \\ Aakriti Gupta ${ }^{6,7,8}$, Mahesh V Madhavan ${ }^{6,7}$, Nandini Nair', Varta Babalyan9 ${ }^{9}$, Nicholas Hutchings@10, \\ Nicola Napoli ${ }^{11,12}$, Domenico Accili', Neil Binkley ${ }^{13}$, Donald W Landry ${ }^{14}$ and Andrea Giustina ${ }^{5}$
}

${ }^{1}$ Endocrinology Division, Department of Medicine, New York-Presbyterian Hospital/Columbia University Irving Medical Center, New York, New York, USA, ${ }^{2}$ Endocrine Unit, Veterans Affairs Medical Center, University of California, San Francisco, California, USA, ${ }^{3}$ Institute of Metabolism and Systems Research, University of Birmingham, Birmingham, UK, ${ }^{4}$ Division of Endocrinology, Escola Paulista de Medicina - Universidade Federal de Sao Paulo (EPM-UNIFESP), Sao Paulo, Brazil, ${ }^{5}$ Institute of Endocrine and Metabolic Sciences, San Raffaele, Vita-Salute University and IRCCS Hospital, Milano, Italy, ${ }^{6}$ Division of Cardiology, Department of Medicine, NewYork-

Presbyterian Hospital/Columbia University Irving Medical Center, New York, New York, USA, ${ }^{7}$ Clinical Trials Center, Cardiovascular Research Foundation, New York, New York, USA, ${ }^{8}$ Center for Outcomes Research and Evaluation, Yale New Haven Hospital, New Haven, Connecticut, USA, ${ }^{9}$ Osteoporosis Center of Armenia, Yerevan, Armenia, ${ }^{10}$ School of Medicine, University of California, Irvine, California, USA, ${ }^{11}$ Unit of Endocrinology and Diabetes, Campus Bio-Medico University of Rome, Rome, Italy, ${ }^{12}$ Division of Bone and Mineral Diseases, Washington University in St Louis, St Louis, Missouri, USA, ${ }^{13}$ University of Wisconsin, Madison, Wisconsin, USA, and ${ }^{14}$ Division of Nephrology, Department of Medicine, NewYork-Presbyterian Hospital/Columbia University Irving Medical Center, New York, New York, USA

Correspondence should be addressed to J P Bilezikian Email jpb2@columbia.edu

\section{Abstract}

The SARS-CoV-2 virus responsible for the COVID-19 pandemic has generated an explosion of interest both in the mechanisms of infection leading to dissemination and expression of this disease, and in potential risk factors that may have a mechanistic basis for disease propagation or control. Vitamin D has emerged as a factor that may be involved in these two areas. The focus of this article is to apply our current understanding of vitamin $D$ as a facilitator of immunocompetence both with regard to innate and adaptive immunity and to consider how this may relate to COVID-19 disease. There are also intriguing potential links to vitamin $D$ as a factor in the cytokine storm that portends some of the most serious consequences of SARS-CoV-2 infection, such as the acute respiratory distress syndrome. Moreover, cardiac and coagulopathic features of COVID-19 disease deserve attention as they may also be related to vitamin D. Finally, we review the current clinical data associating vitamin D with SARS-CoV-2 infection, a putative clinical link that at this time must still be considered hypothetical.

\section{Invited Author's profile}

John P Bilezekian MD, PhD (Hon), Silberberg Professor of Medicine at the Vagelos College of Physicians and Surgeons, Columbia University, New York, USA and is Vice Chair, Department of Medicine for International Education and Research and Chief, Emeritus, of the Division of Endocrinology. He is a major national and international spokesperson for the field of metabolic bone diseases. Dr Bilezikian's major research interests are related to the clinical investigation of metabolic bone diseases, particularly osteoporosis, primary hyperparathyroidism and hypoparathyroidism. He is the recipient of the Distinguished Physician and the Laureate Distinguished Educator Awards of the Endocrine Society, and from the ASBMR the Frederic C. Bartter, the Gideon Rodan Mentorship and the William F Neuman Awards.

Published by Bioscientifica Ltd.

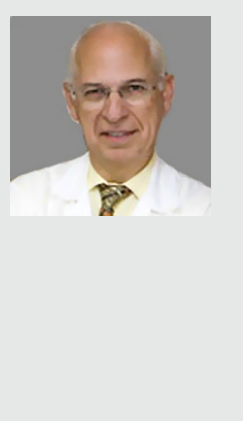




\section{Introduction}

At the time of this writing, SARS-CoV-2, the virus causing the COVID-19 pandemic had infected over 15 million people and had caused over 400000 deaths worldwide (1). In the United States, one of the countries hardest hit by the pandemic, there have been over 4 million people infected and over 140000 deaths. Undoubtedly, these numbers will grow greatly in the months to come. The search for risk factors predisposing to adverse outcomes of this disease has focused upon age, obesity, diabetes, hypertension, ethnicity, and other factors $(2,3,4,5$, $6,7)$. Recently, vitamin $\mathrm{D}$ inadequacy has emerged as another potential risk factor $(8,9,10)$. In view of current interest in vitamin $\mathrm{D}$ as a potential factor in the COVID-19 pandemic, we review what is known about the role of vitamin D as a facilitator of immunocompetence regarding innate and adaptive immunity. We also summarize current information implicating vitamin $\mathrm{D}$ as a factor in the cytokine storm that portends some of the most serious consequences of COVID-19 disease. A discussion of possible involvement of vitamin $\mathrm{D}$ in the cardiac and coagulopathic features of COVID-19 disease is followed by a review of the available clinical data associating vitamin D with SARS-CoV-2, a putative clinical link that, at this time, must still be considered hypothetical.

\section{Vitamin D as a regulator of the immune response}

A major initial observation linking vitamin $\mathrm{D}$ to the immune system was the appreciation that antigen-presenting cells such as macrophages and dendritic cells synthesise the active form of vitamin D, 1,25-dihydroxyvitamin D (1,25 $(\mathrm{OH})_{2} \mathrm{D}$ ) from its precursor 25-hydroxyvitamin D (25OHD) via the enzyme $1 \alpha$-hydroxylase (CYP27B1). This property of macrophages and dendritic cells was initially considered to be a pathological response in association with immune disorders, such as sarcoidosis, tuberculosis, and other granulomatous diseases (11). However, subsequent studies showed that the expression of CYP27B1 and synthesis of $1,25(\mathrm{OH})_{2} \mathrm{D}$ are a fundamental feature in the normal development of antigen-presenting cells $(12,13)$. These seminal observations provided a mechanism by which macrophages and dendritic cells could be influenced by vitamin D. Accompanying these observations is the finding that epithelia, the main barrier between the environment and the body, also express CYP27B1. In general, the epithelia are the first responders to invading pathogens sounding the alarm, as it were, via their own innate immune system to activate dendritic cells and macrophages and to recruit neutrophils and $\mathrm{T}$ cells to the site of infection. In the setting of vitamin D deficiency, immune responses would be impaired because less 25-OHD would be available for synthesis of $1,25(\mathrm{OH})_{2} \mathrm{D}$ leading to impairment of innate immune function (14). This localized, intracrine, mechanism is now considered a cornerstone of the interaction between vitamin $\mathrm{D}$ and the immune system. It is quite distinct from the endocrine actions of vitamin D concerned with regulating mineral homeostasis. Conventional skeletal and calcium regulating effects of vitamin $\mathrm{D}$ are driven by circulating $1,25(\mathrm{OH})_{2} \mathrm{D}$ synthesized primarily by the kidneys. In this conventional setting, $1,25(\mathrm{OH})_{2} \mathrm{D}$ is under the regulation not only by its precursor, 25-OHD but also by parathyroid hormone and fibroblast growth factor 23 (15). In contrast, vitamin D's role in immune response mechanisms appears to be regulated primarily by availability of $25-\mathrm{OHD}$, induction of CYP27B1 by the invading pathogens and, ultimately, by stimulation of $1,25(\mathrm{OH})_{2} \mathrm{D}$ in target tissues of the immune system.

\section{Vitamin $D$ as a regulator of the innate immune response}

\section{Antimicrobial actions of vitamin D and the innate immune response}

An antimicrobial role for $1,25(\mathrm{OH})_{2} \mathrm{D}$ was initially described almost 30 years ago (16). However, the relevance of this antimicrobial property of vitamin D was appreciated only later in studies of the intracellular synthesis of $1,25(\mathrm{OH})_{2} \mathrm{D}$ as a mechanism for promoting antibacterial responses to Mycobacterium tuberculosis. Local, intracellular synthesis of $1,25 \quad(\mathrm{OH})_{2} \mathrm{D}$ by monocytes/macrophages promotes the expression of the antimicrobial protein cathelicidin and enhances intracellular killing of M. tuberculosis. (17). Similar processes occur in epithelia and are an important component of the barrier function that these tissues display. Specifically, the $1,25(\mathrm{OH})_{2} \mathrm{D}$-vitamin $\mathrm{D}$ receptor complex acts on the cathelicidin gene promoter vitamin $\mathrm{D}$ response elements to enhance transcription of cathelicidin (18). Although the antimicrobial function of cathelicidin is crucial, this protein has a number of other functions including the induction of a variety of proinflammatory cytokines, stimulation of the chemotaxis of neutrophils, monocytes, macrophages, and $\mathrm{T}$ cells into the site of infection, and promotion of the clearance of respiratory pathogens by 
inducing apoptosis and autophagy of infected epithelial cells $(19,20)$. The induction of cathelicidin by $1,25(\mathrm{OH})_{2} \mathrm{D}$ is observed only in higher primates, and, thus, it appears that the ability of vitamin $\mathrm{D}$ to promote cathelicidin synthesis is a recent evolutionary development (21). The ability of macrophages to produce cathelicidin correlated well with the serum 25-OHD concentration $(17,22)$. These observations provided a plausible explanation for the reported high prevalence of tuberculosis and various other respiratory disorders in individuals with vitamin D deficiency (23).

In addition to cathelicidin, vitamin $\mathrm{D}$ influences another innate antibacterial element, $\beta$-defensin2 (18). $\beta$-Defensin2, such as cathelicidin, contributes to host defense by stimulating the expression of antiviral cytokines and chemokines involved in the recruitment of monocytes/macrophages, natural killer cells, neutrophils, $\mathrm{T}$ cells (24). Cellular production of cathelcidin and $\beta$-defensin 2 depends on the vitamin $\mathrm{D}$ receptor and CYP27B1 the expressions of which are enhanced following interaction of pathogens with membrane PRRs, such as toll-like receptor 2 and toll-like receptor 4. Another important intracellular pattern recognition receptor, stimulated by $1,25(\mathrm{OH})_{2} \mathrm{D}$, is nucleotidebinding oligomerization domain-containing protein 2 (NOD2) which enhances $\beta$-defensin2 expression (25). Yet another mechanism by which vitamin $\mathrm{D}$ can serve an antimicrobial function relates to cellular iron metabolism. Bacteria depend upon intracellular iron for survival. In the course of infection, hepcidin, which restricts the transcellular export of iron through ferroportin is induced, thus increasing cellular iron levels (26). 1,25 $(\mathrm{OH})_{2} \mathrm{D}$ is a potent suppressor of hepcidin, and therefore acts to enhance ferroportin and reduce intracellular iron, thereby providing another mechanism for suppression of bacterial growth (27). Ultimately, the ability of vitamin $\mathrm{D}$ to promote antimicrobial, innate immune function is closely linked to phagocytosis, and subsequent enhanced bacterial killing via the induction of autophagy (28). Similar considerations pertain to viral clearance as described below. A model for integration of antimicrobial responses to vitamin $\mathrm{D}$, as it relates to $M t b$ is shown in Fig. 1.

Importantly, vitamin $\mathrm{D}$ may have broader antimicrobial actions beyond those described in Fig. 1 , including the generation of nitric oxide (29) and superoxide (30). In addition to enhancing monocyte/ macrophage antimicrobial functions, vitamin D promotes the killing of pneumococcus by stimulating neutrophils via a range of mechanisms that included upregulation

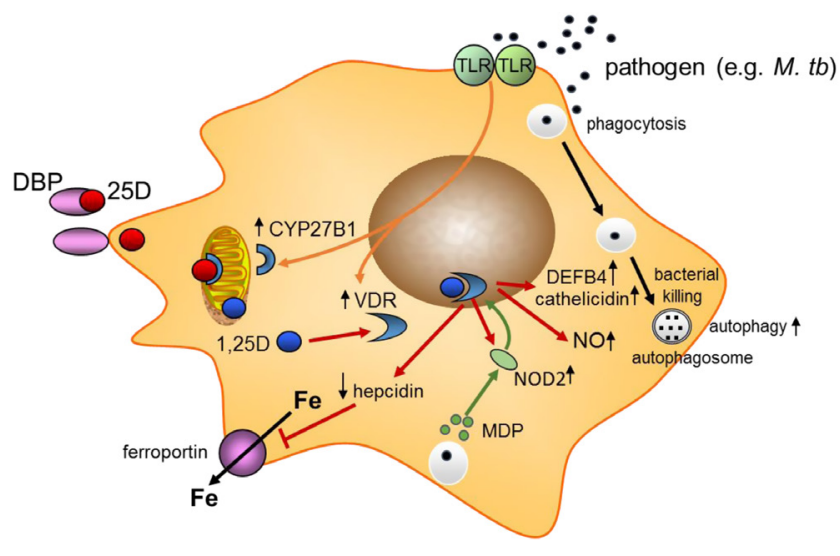

Figure 1

Antimicrobial actions of vitamin D. Schematic showing possible macrophage responses to microbial infection. Pattern recognition receptors such as toll-like receptors (TLR) signal responses to pathogens. This includes transcriptional induction of $1 \alpha$-hydroxylase (CYP27B1) and the vitamin D receptor (VDR). Serum 25-hydroxyvitamin D (25-OHD) bound to vitamin $\mathrm{D}$ binding protein (DBP) allows intracellular access of free 25-OHD for conversion to $1,25(\mathrm{OH})_{2} \mathrm{D}$, which then bind to VDR. Transcriptional responses to $1,25(\mathrm{OH})_{2} \mathrm{D}$ (shown with red arrows) include induction of cathelicidin and $\beta$-defensin 2 (DEFB4), NOD2, and nitric oxide (NO). Intracellular iron (Fe) is exported via ferroportin which is targeted for degradation by hepcidin. The bacterial cell wall product muramyl dipeptide binds to NOD2.

of toll-like receptor 2, NOD2, and cathelicidin together with enhanced antimicrobial human neutrophil peptide (HNP1-3) production (31). Even beyond monocytes, macrophages, and neutrophils, which collectively illustrate the importance of vitamin D in supporting a range of innate antibacterial responses, vitamin $\mathrm{D}$ can promote antimicrobial function outside the immune system. For example, within the gastrointestinal tract, vitamin $\mathrm{D}$ promotes the expression of gap junction proteins that maintain barrier integrity thereby preventing tissue ingress by bacteria from the gut microbiome (32). Similar barrier integrity effects of vitamin $\mathrm{D}$ have also been observed for the epithelial cells of the lung (33), along with stimulation of antimicrobial proteins by lung epithelial cells $(34,35)$.

\section{Antiviral actions of vitamin $D$ and the innate immune response}

Although studies of vitamin D and innate immune activity have focused primarily on antibacterial 
mechanisms, as noted and illustrated in Fig. 1, vitamin $\mathrm{D}$ can also promote antiviral immunity, which is of great importance in any discussion for its role in COVID19 infection. This involves a number of mechanisms that overlap with antibacterial responses, such as the induction of cathelicidin and defensins, which can block viral entry into cells as well as suppress viral replication $(36,37)$. Another property of vitamin D relevant both to antibacterial and antiviral mechanisms are promoting autophagy (38, 39). Autophagy is a fundamental biological process that maintains cellular homeostasis via intracellular membrane encapsulation of damaged organelles and misfolded proteins. Autophagy is also an essential mechanism by which cells deal with viruses. Autophagic encapsulation of viral particles packages them for lysosomal degradation and subsequent antigenpresentation and adaptive antiviral immune responses (40). Thus, autophagy facilitates, but does not guarantee, a hostile cellular antiviral environment.

Induction of autophagy is a key cellular response to vitamin $\mathrm{D}$, with both $25-\mathrm{OHD}$ and $1,25(\mathrm{OH})_{2} \mathrm{D}$ enhancing expression of the autophagy marker LC3 $(28,41)$. Within the innate immune response, vitamin D enhances autophagy by mechanisms similar to the response prompted by antibacterial proteins (42). Thus, autophagy may be sensitive to changes in serum 25-OHD levels. The specific mechanisms by which vitamin D promotes autophagy involves downregulating the mTOR pathway, which inhibits autophagy (43), and by promoting Beclin 1 and PI3KC3, key enzyme drivers of autophagy (44). Upregulation of intracellular Ca and NO by vitamin D also stimulates PI3KC3 activity to promote autophagy (45) (Fig. 2). Beyond the immediate regulation of pathways associated with autophagy induction, vitamin D may also stimulate the formation of autophagosomes to facilitate viral clearance indirectly through induction of cathelicidin expression, which in turn stimulates key autophagy factors such as Beclin 1 (28). In considering the effects of vitamin $\mathrm{D}$ on autophagy, it is important to recognize that these actions are closely linked to apoptosis, which may aid viral replication. Therefore vitamin D may play a crucial role in maintaining appropriate balance between autophagy and apoptosis to maximize antiviral responses to infection (46). Vitamin D-induced autophagy decreases HIV-1 infection $(47,48)$, influenza A (49), rotavirus (50), and hepatitis C (51), but wider virus- and target cell-specific antiviral responses to vitamin $\mathrm{D}$ have been reviewed in detail elsewhere (46).

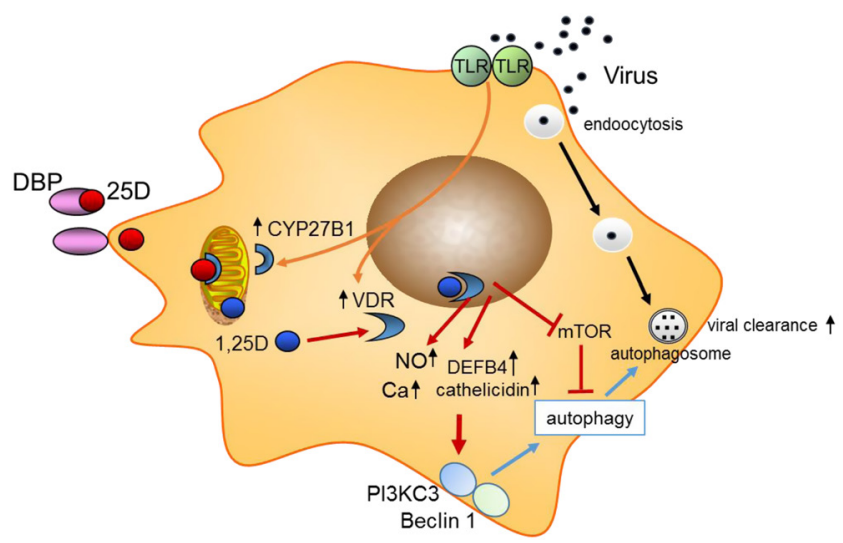

Figure 2

Autophagy and antivirobial actions of vitamin D. Schematic showing possible macrophage responses to viral infection. This includes transcriptional induction of $1 \alpha$-hydroxylase (CYP27B1) and the vitamin D receptor (VDR). Serum 25-hydroxyvitamin D (25-OHD) bound to vitamin D binding protein (DBP) allows intracellular access of free 25-OHD for conversion to $1,25(\mathrm{OH})_{2} \mathrm{D}$, which then bind to VDR.

Transcriptional responses to 1,25 $(\mathrm{OH})_{2} \mathrm{D}$ (shown with red arrows) include induction of cathelicidin and $\beta$-defensin 2 (DEFB4), nitric oxide (NO) and intracellular calcium (Ca).

\section{Vitamin D as a regulator of the adaptive immune response}

The adaptive immune response is initiated by cells specialized in antigen presentation, such as dendritic cells and macrophages, which in turn activate the cells responsible for subsequent antigen recognition, $\mathrm{T}$ and $\mathrm{B}$ lymphocytes. These cells are capable of a wide repertoire of responses that ultimately determine the nature and duration of the immune response. Activation of $\mathrm{T}$ and $\mathrm{B}$ cells occurs after a priming period in tissues of the body, such as lymph nodes, that are typically distant from the site of the initial exposure to the antigenic substance. This period is marked by proliferation of the activated $\mathrm{T}$ and B cells accompanied by post-translational modifications of immunoglobulin production that enable the cellular response to adapt specifically to the antigen presented. The type of T cell activated, CD4 or CD8, or within the helper T cell class Th1, Th2, Th17, Treg, is dependent on the context of the antigen presented by which cell and in what environment. Systemic factors such as vitamin $\mathrm{D}$ influence this process. $1,25(\mathrm{OH})_{2} \mathrm{D}$, in general, exerts an inhibitory, anti-inflammatory, action on the adaptive immune system. When airway dendritic cells are activated 
by a virus, for example, they migrate to lymph nodes where they gain enhanced ability to present antigen for activation of $\mathrm{T}$ cells (52). As noted previously, this activation and maturation of dendritic cells includes increased CYP27B1 expression but also a decrease in the vitamin $\mathrm{D}$ receptor $(21) .1,25(\mathrm{OH})_{2} \mathrm{D}$ decreases the maturation of dendritic cells, decreasing their ability to present antigen and to activate $\mathrm{T}$ cells (53). Treatment of dendritic cells with $1,25(\mathrm{OH})_{2} \mathrm{D}$ can also induce regulatory $\mathrm{T}$ cells (Treg) cells $(54,55)$. Treg cells are critical for the induction of immune tolerance (56) and likely play a key role in preventing the cytokine storm associated with severe respiratory disease caused by viral infections (57).

\section{The vitamin D receptor as a regulator of both innate and adaptive immunity}

Both innate and adaptive immune responses can vary according to different polymorphisms found in many steps of the vitamin D pathway. One of the most studied of these polymorphisms is that related to the vitamin D receptor. By meta-analysis, variability in risk for enveloped virus infection was dependent on the presence of alleles defined by FokI. The majority studies included in this metaanalysis focused on Respiratory Syncytial Virus infection. The recessive genotype TT of Fokl increases susceptibility as compared to CT+CC genotypes. The $\mathrm{T}$ allele reduces the ability of vitamin $\mathrm{D}$ receptor complex to bind to gene elements responsive to vitamin $\mathrm{D}$ and, according to this meta-analysis, it was consistently associated with higher susceptibility to Respiratory Syncytial Virus infections. Moreover, the worldwide distribution of the $\mathrm{T}$ allele overlaps the incidence of Respiratory Syncytial Virus infection, reinforcing the association between vitamin D and immune response against enveloped viruses such as Respiratory Syncytial Virus (58).

\section{The lung as a host for vitamin D-associated immune defense mechanisms}

The lungs are a major target for SARS-CoV-2 and related viruses and, thus, are of major interest in understanding the host immune response to them. The respiratory tract has a large surface area (approximately $70 \mathrm{~m}^{2}$ ) in contact with the environment. Thus, it provides a major site for invasion by pathogenic organisms, against which it must defend. The defense mechanism is composed of both innate and adaptive immunity. Activation of the innate immune system drives the induction of the longterm adaptive immune system (59). The principal cells involved are the airway epithelia, alveolar macrophages, and dendritic cells. These cells all express CYP27B1 and therefore have the potential to synthesize $1,25(\mathrm{OH})_{2} \mathrm{D}$. Expression of CYP27B1 is constitutive in airway epithelial cells (60), but is induced in alveolar macrophages by toll-like receptor (TLR) ligands (e.g. lipopeptide from $M$. tuberculosis), interferon $\gamma(\operatorname{IFN} \gamma)$, and $\operatorname{LPS}(61,62)$, and in dendritic cells by TNF $\alpha$, IFN $\gamma$, polyI:C, and LPS $(63,64$, 65). Moreover, these cells all express pattern recognition receptors (PRRs) of which TLRs are a major component and by which viral RNAs are recognized (66).

Proposed mechanisms for antibacterial and antiviral actions of vitamin D have been derived essentially from in vitro and ex vivo studies, but they have also been used as a rationale for in vivo analysis of the antimicrobial actions of vitamin D. Experiments using animal models have been limited because key antimicrobial responses to vitamin $\mathrm{D}$ such as cathelicidin induction appear to be restricted to primates (21). As outlined earlier, vitamin D deficiency in humans is linked to mycobacterial diseases, such as tuberculosis (67). However, over the last 10 years, vitamin $\mathrm{D}$ deficiency has also been linked to a wide range of common infectious disease, such as sepsis, pneumonia, and MRSA as well as viral infections such as influenza, hepatitis $\mathrm{C}$ and human immunodeficiency virus type 1 (HIV-1) (68). Other viral infections putatively linked to vitamin D include EBS, VZV, CMV, HIV, HCV, HBV, HPV, and Dengue (46). A causal link between low serum 25-OHD and impaired antibacterial and antiviral immunity via the mechanisms outlined in Figs 1 and 2, is plausible given the impact that this will have on intracrine generation of $1,25(\mathrm{OH})_{2} \mathrm{D}$ and subsequent vitamin $\mathrm{D}$ receptor-mediated responses by cells within the immune system and barrier tissue sites.

Although 25-OHD is an important component of antimicrobial responses to vitamin $\mathrm{D}$ via its local conversion to $1,25(\mathrm{OH})_{2} \mathrm{D}$, it is also noteworthy as a circulating lipophilic molecule bound to vitamin D binding protein (69). Thus, the ability of 25-OHD to access target immune cells, such as macrophages and dendritic cells and the epithelia of the lung and skin, is limited by its binding to vitamin D binding protein. Indeed, studies have shown that in fact, it is the relatively small unbound or 'free' fraction of 25-OHD that is acquired by immune cells to drive intracrine induction of antimicrobial responses (70). This suggests that in considering the impact of vitamin D on antimicrobial immune responses, it is important not only to assess the level of 25-OHD but 
also the associated concentration of vitamin D binding protein. It is also possible that infection and associated inflammatory immune responses lead, in turn, to altered vitamin D metabolism, so that low serum 25-OHD could also be a consequence of infectious disease.

\section{Cytokine storm and vitamin D}

One of the devastating pathophysiological aspects of SARS-CoV-2 infection is the so-called pulmonary cytokine storm, a major cause of morbidity and mortality. The cytokine storm results from dysregulation of the innate immune system with an outpouring of proinflammatory cytokines and chemokines, leading to abnormal activation of the adaptive immune pathway. The serious damage caused by coronaviruses such as SARS-COV-2 is due to their infection of both the upper and lower airways with rapid virus replication, massive inflammatory cell infiltration producing a huge increase in proinflammatory cytokines and chemokines leading to acute respiratory distress syndrome (71). The initial infection of the airway epithelium leads to rapid viral replication $(72,73)$ complicated by a virus-induced delayed increase in class 1 interferon (IFN $\alpha / \beta)$ expression in dendritic cells that would normally block viral replication and enhance viral clearance by CD8 T cells (74). The delayed expression of class 1 interferon subsequently increases recruitment of proinflammatory cells, contributing to the problem. These infected airway epithelial cells then secrete a number of proinflammatory cytokines/chemokines that further dysregulate the innate immune response and attract the influx of inflammatory cells including neutrophils, monocytes and macrophages while sensitizing $\mathrm{T}$ cells to apoptosis (75). The consequences include a breakdown in the microvascular and alveolar epithelial barrier from apoptosis of the lung epithelium and endothelium, resulting in vascular leakage and alveolar edema. The $\mathrm{T}$ cell response required for viral clearance is blunted (76), and their role in dampening the cytokine storm is reduced.

A potential role for vitamin $\mathrm{D}$ in modulating these pathophysiological aspects of the cytokine storm is noteworthy. Airway epithelia constitutively express both CYP27B1, $1,25(\mathrm{OH})_{2} \mathrm{D}$, and the vitamin $\mathrm{D}$ receptor. Furthermore, pulmonary alveolar macrophages are induced to express both CYP27B1 and the vitamin D receptor by pathogens such as viruses and cytokines released from infected cells. Although not demonstrated for coronaviruses, such as SARS-CoV-2, for other viruses and other respiratory pathogens, activation of innate immunity leading to increased local $1,25(\mathrm{OH})_{2} \mathrm{D}$ production has been shown to enhance viral neutralization and clearance while modulating the subsequent proinflammatory response. Whether this sequence of events will be the case for SARS-CoV-2 remains to be seen.

\section{Summary of molecular features that could link vitamin D to COVID-19 infection}

The innate immune system is the first line of defense against invading pathogens, such as viruses. It is prebuilt, relying on constitutive expression of pattern recognition receptors like TLRs to identify such pathogens. $1,25(\mathrm{OH})_{2} \mathrm{D}$ enhances that defense by inducing antimicrobial peptides such as cathelicidin that lead to viral destruction and clearance by several mechanisms, helps recruit neutrophils, monocytes/macrophages, and dendritic cells which further the killing and clearance of these pathogens, and initiates the adaptive immune response. While beneficial acutely, chronic activation of the innate immune response is not necessarily beneficial, and can result in a cytokine storm. $1,25(\mathrm{OH})_{2} \mathrm{D}$ works to curtail this chronic innate immune response through a number of mechanisms including down regulation of TLRs and direction inhibition of $\mathrm{TNF} / \mathrm{NFKB}$ and IFN $\gamma$ signaling pathways. The adaptive immune system provides a more specific response, but takes longer to develop, although once developed provides a powerful response against invading organisms. However, this response if not controlled can also be destructive. Vitamin D, via its active metabolite $1,25(\mathrm{OH})_{2} \mathrm{D}$, regulates adaptive immunity by limiting the maturation of dendritic cells, limiting their ability to present antigen to $\mathrm{T}$ cells, and shifting the $\mathrm{T}$ cell profile from the proinflammatory Th1 and Th17 subsets to Th2 and Treg subsets, which inhibit the proinflammatory processes. Although these results come from studies with a variety of pathogens, viral and bacterial, the relevance of these protective actions on SARS-CoV-2 merits further investigation.

\section{Vitamin D and the cardiovascular system in COVID-19}

COVID-19 has been associated with cardiovascular sequelae, including myocardial injury, type 1 myocardial infarction, acute coronary syndromes, acute cor pulmonale, cardiomyopathy, arrhythmias, thrombotic complications, and cardiogenic shock $(77,78,79)$. Myocardial injury, 
with the elevation of cardiac biomarkers as well as electrocardiographic or echocardiographic changes, is common, reported in 20-30\% of hospitalized patients with COVID-19 (80, 81). Cardiomyopathy has been reported in $7-33 \%$ of critically ill COVID-19 patients (82, 83, 84). Cardiac arrhythmias, including new onset atrial fibrillation and atrial flutter, heart block, and ventricular arrhythmias have been reported in $17 \%$ of hospitalized patients, and $44 \%$ of patients in the ICU setting (85).

Preclinical evidence suggests that vitamin D may protect against atherosclerosis, a substrate for deleterious myocardial events, by inhibiting the transformation of macrophages to foam cells and by increasing cholesterol efflux $(86,87)$. 1,25 $(\mathrm{OH})_{2} \mathrm{D}$-induced production of vascular endothelial growth factor in vascular smooth muscle cells has been proposed to promote endothelial repair (88). Anti-inflammatory actions such as reduced $\mathrm{NF \kappa B}$ and interleukin 6 expression in endothelial cells, reduced thrombogenicity - through the downregulation of tissue factor (F3) and upregulation of thrombomodulin expression in endothelial cells and macrophages, and increased endothelial nitric oxide production are some of the other possible antiatherosclerotic mechanisms of vitamin D (88). The effects of vitamin D on vascular calcification, however, can be 'double-edged' because both deficiency and excess vitamin $\mathrm{D}$ has been associated with vascular calcification, a key component of atherosclerotic cardiovascular disease (88).

While no direct causal evidence for a role of vitamin D deficiency in SARS-CoV-2-related heart disease is available, extrapolation of evidence from prior animal and human studies permits speculation of several plausible mechanisms. The rather widespread presence of CYP27B1 includes cells of the cardiovascular system (89, 90). Furthermore, the vitamin D receptor for $1,25(\mathrm{OH})_{2} \mathrm{D}$ is expressed in the heart and blood vessels $(84,86)$. In mice models in which the CYP27B1 or the vitamin D receptor has been knocked out systemically, myocardial hypertrophy with overexpression of the reninangiotensin-aldosterone system (RAAS), hypertension, increased thrombogenicity, and progression of atherosclerosis have been reported $(89,91)$. The proposed overexpression of the RAAS system, fits these sequelae of vitamin $\mathrm{D}$ deficiency in animal models. The various cardiovascular risk factors that have been correlated with higher mortality from COVID-19 are also more evident in experimental and clinical studies of vitamin D deficiency $(92,93,94,95,96,97,98)$. Such risk factors for cardiovascular disease in COVID-19 disease, which are linked to vitamin D deficiency include hypertension (99), diabetes (100), obesity (101) and chronic kidney disease (102). In particular, vitamin D deficiency may predispose to hypertension by upregulation of the RAAS, and increasing vascular resistance and vasoconstriction (103, 104, 105). In mice with endothelial-specific knockout of the vitamin D receptor gene, vascular function is significantly altered, with increased sensitivity to angiotensin-2 compared with control mice (106). It is possible that this is further exacerbated by SARS-CoV-2 infection, in which viral binding with cellular entry receptor ACE2 leads to dysregulation of the RAAS in favour of angiotensin-2 $(107,108,109)$.

Activation of the vitamin $\mathrm{D}$ receptor also modulates myocardial contractility, likely by regulating calcium flux (110). Several meta-analyses of prospective clinical studies have consistently shown that low 25-OHD serum concentrations indicate an increased risk of overall cardiovascular events and cardiovascular mortality $(111,112,113,114,115,116)$. While a majority of the randomized controlled trials examining effects of vitamin D supplementation have not shown benefit, the VINDICATE study demonstrated beneficial effects for improvement in left ventricular rejection fraction and reversal of left ventricular remodeling in patients with chronic heart failure who received vitamin D (117).

Patients with COVID-19 are also at risk for a number of thrombotic complications (118), which may be due to a number of direct and indirect effects of SARS-CoV-2 infection. Several reports have suggested elevated rates of both arterial and venous thrombotic events in patients with COVID-19 $(119,120,121,122,123)$ and significant coagulopathy is related to poor prognosis in COVID-19 patients $(118,121)$. While the mechanisms which lead to these events have yet to be fully elucidated, it is plausible that vitamin D levels may be a contributing risk factor. The vitamin D receptor is expressed ubiquitously in blood vessels (90). The possible interaction between inflammatory and hemostatic pathways and vitamin D status is supported by both preclinical and clinical data. Mice in which the vitamin D receptor has been knocked out demonstrate enhanced platelet aggregation, downregulation of antithrombin and thrombomodulin gene expression, and upregulation of tissue factor expression (124). Other studies have suggested that 1,25 $(\mathrm{OH})_{2} \mathrm{D}$ can downregulate proinflammatory signaling and promote inhibition of tissue factor activity, thus reducing a prothrombotic milieu (125). In addition, a limited number of clinical reports, antedating the COVID-19 era suggest a link between the development of vitamin $\mathrm{D}$ deficiency and incident thrombotic events, including 
deep venous thrombosis and cerebrovascular events (126, $127,128)$. This may be especially true in patients who are critically ill and require intensive care, among whom low 25 -OHD levels have been reported in up to $80 \%$ in the pre-COVID-19 era $(129,130)$. However, it remains unclear whether vitamin D supplementation in such patients has an effect on outcomes (131).

Given the relationship between vitamin $\mathrm{D}$ and the RAAS, inflammatory and hemostatic pathways, all of which have been implicated in the development of cardiovascular complications from SARS-CoV-2 infection, further studies evaluating the role of vitamin $\mathrm{D}$ in COVID-19-related cardiovascular and thrombotic events may prove critical to gaining insights into both mechanism and therapeutics.

\section{Clinical data linking vitamin D to pulmonary infections}

Historically and well before the sun was linked to vitamin D metabolism and activation, it occupied a central position in popular lore as a source of life. The Hindu prayer Surya Namascar is based on the myth of Samba, the son of Krishna, who was cured of leprosy by praying to Surya, a solar deity (132). Until the beginning of the last century, sanatoriums to treat tuberculosis were commonly located in sunny places, where sunbathing was part of the treatment. Interestingly, cod liver oil was used to treat tuberculosis in the 19th century, even before knowing that it was extremely rich in vitamin D (133). Recognition that the vitamin D precursor in the skin is thermoactivated by sunlight has been known only for the past 100 years (134). So intense is the activation of the vitamin D pathway by macrophages and other immuneoriented cells that $1,25(\mathrm{OH})_{2} \mathrm{D}$-dependent hypercalcemia can occur in patients with granulomatous diseases, such as tuberculosis or other granulomatous diseases (135). However, the enticing historical backdrop to vitamin D as a therapeutic for tuberculosis has not met with general consensus (136). Nevertheless, a recent meta-analysis evaluating the effects of vitamin D supplementation on different outcomes in 1787 patients with pulmonary tuberculosis demonstrated some benefits and concluded that this supplementation should be considered as an adjuvant therapy, together with antibiotics (137).

The link between vitamin D and viral infections arose from the observation of the seasonality of vitamin D with lower levels in the winter and concomitant increases in influenza. Conversely, in summer, serum levels of 25-OHD increase and influenza virtually disappears, except during pandemics. Even in pandemics, most deaths occur during cold months (138).

Lower 25-OHD concentrations are associated with a higher risk for infections, especially from the respiratory tract (139). Seeking a link to acute respiratory infections, Sabetta et al. measured monthly 25-OHD concentrations in 198 healthy adults and followed them during fall and winter (140). Individuals with 25 -OHD concentrations $\geq 38$ $\mathrm{ng} / \mathrm{mL}$ had a two-fold lower risk of viral acute respiratory infections and faster recovery, compared to those with lower concentrations $(P<0.0001)$. Other studies have also found an association between lower levels of 25-OHD and higher risk of acute respiratory infections but with different thresholds. Nevertheless, they are consistent in showing that the lower the 25-OHD concentration, the greater the risk for acute respiratory infections. Generally, higher-risk occurred at 25-OHD concentrations below 20 $\mathrm{ng} / \mathrm{mL}$, but in a retrospective study of 14108 individuals from the National Health and Nutrition Examination Survey, levels $<30 \mathrm{ng} / \mathrm{mL}$ were associated with $58 \%$ higher odds of acute respiratory infections $(141,142,143)$.

Recently, Martineau et al. reported the effects of Vitamin D supplementation to prevent acute respiratory infections (144). This meta-analysis included 25 randomized double-blind placebo-controlled trials with individual data from 10933 patients across the lifespan. Vitamin D supplementation decreased risk of respiratory tract infections by $12 \%$. A stronger protective effect was observed in those with baseline levels of 25-OHD $<10 \mathrm{ng} /$ $\mathrm{mL}$ compared with those with a baseline levels $>10 \mathrm{ng} /$ $\mathrm{mL}$. This protective effect was much more evident in those receiving daily or weekly doses of vitamin $\mathrm{D}$ in contrast to those receiving bolus doses. When combining the daily and weekly doses, the protective effect was more evident at baseline concentrations $<10 \mathrm{ng} / \mathrm{mL}$ but also at baseline levels $\geq 10 \mathrm{ng} / \mathrm{mL}$.

\section{Clinical data linking Vitamin D to COVID-19 infection}

In a small study $(n=20)$ of hospitalized COVID-19 patients, vitamin D insufficiency (defined as levels of $25-\mathrm{OHD}<30 \mathrm{ng} / \mathrm{mL}$ ) was present in $75 \%$ of the overall cohort and in $85 \%$ of those who required ICU care $(n=13)$ (145). Additionally, an analysis of COVID-19 severity based on survey vitamin D status in Europe suggested that countries with highest rate of vitamin D deficiency are associated with highest rates of infection and death (146). 
Furthermore, a preliminary study from the United States has found a strong correlation of vitamin D deficiency with mortality and other aspects of poorer outcome (147).

Recently, Ilie et al. observed a significant negative correlation between historical mean25-OHD concentrations per European country with COVID-19 mortality and number of cases (148). Following similar reasoning, Marik et al. observed a higher fatality rate for COVID-19 for Northern $\left(>40^{\circ} \mathrm{N}\right.$ latitude) vs Southern states $(6.0 \%$ vs $3.5 \%, P<0.001)$ in the US (149). Very recently, Gennari et al. reports lower levels of 25-OHD levels among patients hospitalized with COVID-19 in Italy (150). In the aggregate, these data suggest a potential deleterious effect of vitamin D deficiency on risk and outcome in COVID-19 disease.

D'Avolio et al. investigated retrospectively 25-OHD concentrations in 107 patients who were tested for COVID-19 by nasopharyngeal swab from March 1 to April 14,2020 , in a single hospital from Switzerland (151). The median 25-OHD level was $22.2 \mathrm{ng} / \mathrm{mL}$, similar to the median of a control cohort from the same period in 2019 $(24.6 \mathrm{ng} / \mathrm{mL})$. In the 27 individuals with PCR positivity for SARS-COVID-2, the median 25-OHD was $11.1 \mathrm{ng} / \mathrm{mL}$ while in those who were PCR negative, the median was $24.6 \mathrm{ng} / \mathrm{mL} ; P<0.004$. This relationship, however, was not found by Hastie et al. using UK biobank data (152). They investigated 449 individuals with confirmed COVID-19 infection who had 25-OHD concentrations obtained 10 years before. The initial inverse association disappeared after adjustment for confounders. Male sex, poorer health status, socioeconomic deprivation, age, BMI, and ethnicity were predictive factors for COVID-19 in a multivariable logistic regression. Curiously, they could also not find any association of this viral infection with diabetes, blood pressures, or smoking. Grant et al. have provided evidence that vitamin D supplementation might be associated with reduce risk of COVID-19 infections and deaths (153).

It is intriguing that, Italy and Spain, which have been heavily affected by COVID-19 are among the European Countries with the highest prevalence of hypovitaminosis D (142). In a sampling of 700 Italian women, 60-80 years old, 25-OHD levels were reported to be lower than $12 \mathrm{ng} / \mathrm{mL}$ in $76 \%$ (154). Moreover, prevalence of hypovitaminosis D was reported in up to $32 \%$ of healthy postmenopausal women in winter and more than $80 \%$ in institutionalized individuals (155). Diabetes and obesity, recognized risk factors for the disease or for its severity, are characterized by poor vitamin D status and elevated vitamin D requirements $(154,156)$. In the vast majority of hospitalized elderly Italian subjects, hypovitaminosis D was present with more than half showing severe vitamin D deficiency. Lack of vitamin D also correlated with inflammatory parameters (157).

Endogenous levels of 25-OHD are dependent, to variable extent on sun irradiation, particularly in those countries where foods are not fortified in vitamin D. Low vitamin D status could potentially be a mechanistic link between age, comorbidities and increased susceptibility to complications and mortality due to COVID-19 at least in some countries $(9,148)$. However, in Italy, vitamin $\mathrm{D}$ is predominantly prescribed to post-menopausal women with osteoporosis and for this reason, it can be hypothesized that older men are, at least in part, more vulnerable to the most serious consequences of the infection on this basis $(153,158)$

The available clinical data, in brief, are still very preliminary with regard to vitamin $\mathrm{D}$ status and COVID-19 disease. Many reports, to date, have been published without rigorous peer-review, are retrospective, and only associative. Caution is, therefore necessary in interpreting the data. Nevertheless, recent publications consistently show a higher prevalence of vitamin D deficiency in patients presenting with severe forms of COVID-19 (153). In addition, putative mechanisms underlying vitamin D's role in immunity and nonskeletal actions, would provide support for the hypothesis advanced that vitamin D deficiency is a risk factor for the disease and/or its adverse outcome. Clearly, there are other factors to consider that include not only established risk factors $(159,160,161)$ but also local public health measures that are taken to control the spread of the SARS-CoV-2 virus.

An increasing number of clinical trials are being registered to investigate the effect of vitamin D supplementation or 25-OHD levels on various COVID-19 outcomes (159). Until the results of these trials are known, a prudent, general health measure is to ensure vitamin D sufficiency. For most individuals worldwide, this recommendation comes with the need for vitamin D supplementation in order to maintain adequate circulating levels of 25-OHD.

\section{Conclusions}

The pervasive actions of vitamin D on many organ systems have raised many possible interactions between it and the mechanisms by which the SARS-CoV- 2 virus infects human beings. While the data are far from conclusive in attributing a role for vitamin D in influencing the risk and 
outcome of this disease, it is nevertheless also clear that more research would be timely and revealing.

\section{Declaration of interest}

The authors declare that there is no conflict of interest that could be perceived as prejudicing the impartiality of this review.

\section{Funding}

This work did not receive any specific grant from any funding agency in the public, commercial, or not-for-profit sector.

\section{Acknowledgements}

All authors contributed to this manuscript either by drafting sections of it, providing conceptual guidance, reviewing the drafts and in valuable discussions. This study was not funded by any outside agencies.

\section{References}

1 Dong E, Du H \& Gardner L. An interactive web-based dashboard to track COVID-19 in real time. Lancet Infectious Diseases 202020 533-534. (https://doi.org/10.1016/S1473-3099(20)30120-1)

2 Guan WJ, Ni ZY, Hu Y, Liang WH, Ou CQ, He JX, Liu L, Shan H, Lei CL, Hui DSC et al. Clinical characteristics of coronavirus disease 2019 in China. New England Journal of Medicine 2020382 1708-1720. (https://doi.org/10.1056/NEJMoa2002032)

3 Shi S, Qin M, Shen B, Cai Y, Liu T, Yang F, Gong W, Liu X, Liang J, Zhao Q et al. Association of cardiac injury with mortality in hospitalized patients with COVID-19 in Wuhan, China. JAMA Cardiology 202025 802-810. (https://doi.org/10.1001/ jamacardio.2020.0950)

4 Zhou F, Yu T, Du R, Fan G, Liu Y, Liu Z, Xiang J, Wang Y, Song B, $\mathrm{Gu} \mathrm{X}$ et al. Clinical course and risk factors for mortality of adult inpatients with COVID-19 in Wuhan, China: a retrospective cohort study. Lancet 2020395 1054-1062. (https://doi.org/10.1016/S01406736(20)30566-3)

5 Wu C, Chen X, Cai Y, Xia J, Zhou X, Xu S, Huang H, Zhang L, Zhou X, Du C et al. Risk factors associated with acute respiratory distress syndrome and death in patients with coronavirus disease 2019 pneumonia in Wuhan, China. JAMA Internal Medicine 2020180 1-11. (https://doi.org/10.1001/jamainternmed.2020.0994)

6 Chen T, Wu D, Chen H, Yan W, Yang D, Chen G, Ma K, Xu D, Yu H, Wang $\mathrm{H}$ et al. Clinical characteristics of 113 deceased patients with coronavirus disease 2019: retrospective study. BMJ 2020368 m1091. (https://doi.org/10.1136/bmj.m1091)

7 Petrilli CM, Jones SA, Yang J, Rajagopalan H, O’Donnell L, Chernyak Y, Tobin KA, Cerfolio RJ, Francois F \& Horwitz LI. Factors associated with hospital admission and crticial illness among 5279 people with coronavirus disease 2019 in New York City: a prospective cohort study. BMJ 2020369 m1966. (https://doi.org/10.1136/bmj. m1966)

8 Mitchell F. Vitamin-D and COVID-19: do deficient risk a poorer outcome? Lancet: Diabetes and Endocrinology 20208 570. (https://doi. org/10.1016/S2213-8587(20)30183-2)

9 Marazuela M, Giustina A \& Puig-Domingo M. Endocrine and metabolic aspects of the COVID-19 pandemic.Reviews in Endocrine and Metabolic Disorders 2020 In press. (https://doi.org/10.1007/ s11154-020-09569-2)

10 Hastie CE, Mackay DF, Ho F, Celis-Morales CA, Katikireddi SV, Niedzwiedz CL, Jani BD, Welsh P, Mair FS, Gray SR et al. Vitamin D concentrations and COVID-19 infection in UK Biobank. Diabetes and Metabolic Syndrome: Clinical Research and Reviews 202014 561-565. (https://doi.org/10.1016/j.dsx.2020.04.050)

11 Kallas M, Green F, Hewison M, White C \& Kline G. Rare causes of calcitriol-mediated hypercalcemia: a case report and literature review. Journal of Clinical Endocrinology and Metabolism 201095 3111-3117. (https://doi.org/10.1210/jc.2009-2673)

12 Kreutz M, Andreesen R, Krause SW, Szabo A, Ritz E \& Reichel H. 1,25-Dihydroxyvitamin D3 production and vitamin D3 receptor expression are developmentally regulated during differentiation of human monocytes into macrophages. Blood 199382 1300-1307.

13 Hewison M, Freeman L, Hughes SV, Evans KN, Bland R, Eliopoulos AG, Kilby MD, Moss PA \& Chakraverty R. Differential regulation of vitamin $\mathrm{D}$ receptor and its ligand in human monocytederived dendritic cells. Journal of Immunology $20031705382-5390$. (https://doi.org/10.4049/jimmunol.170.11.5382)

14 Hewison M. Vitamin D and the intracrinology of innate immunity. Molecular and Cellular Endocrinology 2010321 103-111. (https://doi. org/10.1016/j.mce.2010.02.013)

15 Haussler MR, Whitfield GK, Kaneko I, Haussler CA, Hsieh D, Hsieh JC \& Jurutka PW. Molecular mechanisms of vitamin D action. Calcified Tissue International 201392 77-98. (https://doi.org/10.1007/s00223012-9619-0)

16 Rook GA, Steele J, Fraher L, Barker S, Karmali R, O’Riordan J \& Stanford J. Vitamin D3, gamma interferon, and control of proliferation of Mycobacterium tuberculosis by human monocytes. Immunology 198657 159-163.

17 Liu PT, Stenger S, Li H, Wenzel L, Tan BH, Krutzik SR, Ochoa MT, Schauber J, Wu K, Meinken C et al. Toll-like receptor triggering of a vitamin D-mediated human antimicrobial response. Science $2006 \mathbf{3 1 1}$ 1770-1773. (https://doi.org/10.1126/science.1123933)

18 Wang TT, Nestel FP, Bourdeau V, Nagai Y, Wang Q, Liao J, TaveraMendoza L, Lin R, Hanrahan JW, Mader S et al. Cutting edge: 1,25-dihydroxyvitamin D3 is a direct inducer of antimicrobial peptide gene expression. Journal of Immunology 2004173 2909-2912. (https://doi.org/10.4049/jimmunol.173.5.2909)

19 Greiller CL \& Martineau AR. Modulation of the immune response to respiratory viruses by vitamin D. Nutrients $201574240-4270$. (https://doi.org/10.3390/nu7064240)

20 Yuk JM, Shin DM, Lee HM, Yang CS, Jin HS, Kim KK, Lee ZW, Lee SH, Kim JM \& Jo EK. Vitamin D3 induces autophagy in human monocytes/macrophages via cathelicidin. Cell Host and Microbe 2009 6 231-243. (https://doi.org/10.1016/j.chom.2009.08.004)

21 Gombart AF, Borregaard N \& Koeffler HP. Human cathelicidin antimicrobial peptide (CAMP) gene is a direct target of the vitamin D receptor and is strongly up regulated in myeloid cells by 1,25-dihydroxyvitamin D3. FASEB Journal 200519 1067-1077. (https://doi.org/10.1096/fj.04-3284com)

22 Adams JS, Ren S, Liu PT, Chun RF, Lagishetty V, Gombart AF, Borregaard N, Modlin RL \& Hewison M. Vitamin D-directed rheostatic regulation of monocyte antibacterial responses. Journal of Immunology 2009182 4289-4295. (https://doi.org/10.4049/ jimmunol.0803736)

23 Chan TY. Vitamin D deficiency and susceptibility to tuberculosis. Calcified Tissue International 200066 476-478. (https://doi. org/10.1007/s002230010095)

24 Kim J, Yang YL, Jang SH \& Jang YS. Human beta-defensin 2 plays a regulatory role in innate antiviral immunity and is capable of potentiating the induction of antigen-specific immunity. Virology Journal 201815 124. (https://doi.org/10.1186/s12985-018-1035-2)

25 Wang TT, Dabbas B, Laperriere D, Bitton AJ, Soualhine H, TavertaMendoza LE, Dionne S, Servant MJ, Bitton A, Seidman EG et al. Direct and indirect induction by 1,25 dihydroxyvitamin D3 of the NOD2/CARD15-defensin beta2 innate immune pathway defective in Crohn disease. Journal of Biological Chemistry 2010285 2227-2231. (https://doi.org/10.1074/jbc.C109.071225) 
26 Hepcidin GT. A peptide hormone at the interface of innate immunity and iron metabolism. Current Topics in Microbiology and Immunology 2006306 183-198

27 Bacchetta J, Zaritsky JJ, Sea JL, Chun RF, Lisse TS, Zavala K, Nayak A, Wesseling Perry K, Westerman M, Hollis BW et al. Suppression of iron-regulatory hepcidin by vitamin D. Journal of the American Society of Nephrology 201425 564-572. (https://doi.org/10.1681/ ASN.2013040355)

28 Yuk JM, Shin DM, Lee HM, Yang CS, Jin HS, Kim KK, Lee ZW, Lee SH, Kim JOM \& Jo EK. Vitamin D3 induces autophagy in human monocytes/macrophages via cathelicidin. Cell Host and Microbe 20096 231-243. (https://doi.org/10.1016/j. chom.2009.08.004)

29 Gough ME, Graviss EA \& May EE. The dynamic immunomodulatory effects of vitamin D3 during Mycobacterium infection. Innate Immunity 201723 506-523. (https://doi. org/10.1177/1753425917719143)

30 Hubel E, Kiefer T, Weber J, Mettang T \& Kuhlmann U. In vivo effect of 1,25-dihydroxyvitamin D3 on phagocyte function in hemodialysis patients. Kidney International 199140 927-933. (https://doi. org/10.1038/ki.1991.296)

31 Subramanian K, Bergman P \& Henriques-Normark B. Vitamin D promotes pneumococcal killing and modulates inflammatory responses in primary human neutrophils. Journal of Innate Immunity 20179 375-386. (https://doi.org/10.1159/000455969)

32 Kong J, Zhang Z, Musch MW, Ning G, Sun J, Hart J, Bissonnette M $\&$ Li YC. Novel role of the vitamin D receptor in maintaining the integrity of the intestinal mucosal barrier. American Journal of Physiology: Gastrointestinal and Liver Physiology 2008294 G208-G216. (https://doi.org/10.1152/ajpgi.00398.2007)

33 Shi YY, Liu TJ, Fu JH, Xu W, Wu LL, Hou AN \& Zue XD. Vitamin D/ VDR signaling attenuates lipopolysaccharideinduced acute lung injury by maintaining the integrity of the pulmonary epithelial barrier. Molecular Medicine Reports 201613 1186-1194. (https://doi. $\operatorname{org} / 10.3892 / \mathrm{mmr} .2015 .4685)$

34 Schrumpf JA, van Sterkenburg MAJA, Verhoosel RM, Zuyderduyn S \& Hiemstra PS. Interleukin 13 exposure enhances vitamin D-mediated expression of the human cathelicidin antimicrobial peptide 18/ LL-37 in bronchial epithelial cells. Infection and Immunity $2012 \mathbf{8 0}$ 4485-4494. (https://doi.org/10.1128/IAI.06224-11)

35 van der Does AM, Bergman P, Agerberth B \& Lindbom L. Induction of the human cathelicidin LL-37 as a novel treatment against bacterial infections. Journal of Leukocyte Biology 201292 735-742. (https://doi.org/10.1189/jlb.0412178)

36 Ahmed A, Siman-Tov G, Hall G, Bhalla N \& Narayanan A. Human antimicrobial peptides as therapeutics for viral infections. Viruses 201911 704. (https://doi.org/10.3390/v11080704)

37 Barlow PG, Svoboda P, Mackellar A, Nash AA, York IA, Pohl J, Davidson DJ \& Donis RO. Antiviral activity and increased host defense against influenza infection elicited by the human cathelicidin LL-37. PLOS ONE 20116 e25333. (https://doi. org/10.1371/journal.pone.0025333)

38 Campbell GR \& Spector SA. Autophagy induction by vitamin D inhibits both Mycobacterium tuberculosis and human immunodeficiency virus type 1. Autophagy 20128 1523-1525. (https://doi.org/10.4161/auto.21154)

39 Campbell GR \& Spector SA. Vitamin D inhibits human immunodeficiency virus type 1 and Mycobacterium tuberculosis infection in macrophages through the induction of autophagy. PLoS Pathogens 20128 e1002689. (https://doi.org/10.1371/journal. ppat.1002689)

40 Mao J, Lin E, He L, Yu J, Tan P \& Zhou Y. Autophagy and viral infection. Advances in Experimental Medicine and Biology 20191209 55-78. (https://doi.org/10.1007/978-981-15-0606-2_5)

41 Mushegian AA. Autophagy and vitamin D. Science Signaling 201710 eaan2526. (https://doi.org/10.1126/scisignal.aan2526)
42 Shin DM, Yuk JM, Lee HM, Lee SH, Son JW, Harding CV, Kim JM, Modlin RL \& Jo EK. Mycobacterial lipoprotein activates autophagy via TLR2/1/CD14 and a functional vitamin D receptor signalling. Cellular Microbiology 201012 1648-1665. (https://doi.org/10.1111/ j.1462-5822.2010.01497.x)

43 Jang W, Kim HJ, Li H, Jo KD, Lee MK, Song SH \& Yang HO. 1,25-Dyhydroxyvitamin $\mathrm{D}(3)$ attenuates rotenone-induced neurotoxicity in SH-SY5Y cells through induction of autophagy. Biochemical and Biophysical Research Communications 2014451 142-147. (https://doi.org/10.1016/j.bbrc.2014.07.081)

44 Wang J. Beclin 1 bridges autophagy, apoptosis and differentiation. Autophagy 20084 947-948. (https://doi.org/10.4161/auto.6787)

45 Uberti F, Lattuada D, Morsanuto V, Nava U, Bolis G, Vacca G, Squarzanti DF, Cisari C \& Molinari C. Vitamin D protects human endothelial cells from oxidative stress through the autophagic and survival pathways. Journal of Clinical Endocrinology and Metabolism 201499 1367-1374. (https://doi.org/10.1210/jc.2013-2103)

46 Teymoori-Rad M, Shokri F, Salimi V \& Marashi SM. The interplay between vitamin D and viral infections. Reviews in Medical Virology 201929 e2032. (https://doi.org/10.1002/rmv.2032)

47 Campbell GR\& Spector SA. Hormonally active vitamin D3 (1alpha,25 dihydroxycholecalciferol) triggers autophagy in human macrophages that inhibits HIV-1 infection. Journal of Biological Chemistry 2011286 18890-18902. (https://doi.org/10.1074/jbc. M110.206110)

48 Campbell GR \& Spector SA. Toll-like receptor 8 ligands activate a vitamin $\mathrm{D}$ mediated autophagic response that inhibits human immunodeficiency virus type 1. PLoS Pathogens 20128 e1003017. (https://doi.org/10.1371/journal.ppat.1003017)

49 Khare D, Godbole NM, Pawar SD, Mohan V, Pandey G, Gupta S, Kumar D, Dhole TN \& Bodbole MM. Calcitriol [1, 25[OH]2 D3] preand post-treatment suppresses inflammatory response to influenza A (H1N1) infection in human lung A549 epithelial cells. European Journal of Nutrition 201352 1405-1415. (https://doi.org/10.1007/ s00394-012-0449-7)

50 Tian G, Liang X, Chen D, Mao X, Yu J, Zheng P, He J, Huang Z \& Yu B. Vitamin D3 supplementation alleviates rotavirus infection in pigs and IPEC-J2 cells via regulating the autophagy signaling pathway. Journal of Steroid Biochemistry and Molecular Biology 2016 163 157-163. (https://doi.org/10.1016/j.jsbmb.2016.05.004)

51 Abdel-Mohsen MA, El-Braky AA-A, Ghazal AAE \& Shamseya MM. Autophagy, apoptosis, vitamin $\mathrm{D}$, and vitamin $\mathrm{D}$ receptor in hepatocellular carcinoma associated with hepatitis C virus. Medicine 201897 e0172. (https://doi.org/10.1097/ MD.0000000000010172)

52 Holt PG, Strickland DH, Wikstrom ME \& Jahnsen FL. Regulation of immunological homeostasis in the respiratory tract. Nature Reviews: Immunology 20088 142-152. (https://doi.org/10.1038/nri2236)

53 van Etten E \& Mathieu C. Immunoregulation by 1,25-dihydroxyvitamin D3: basic concepts. Journal of Steroid Biochemistry and Molecular Biology 200597 93-101. (https://doi. org/10.1016/j.jsbmb.2005.06.002)

54 Gregori S, Casorati M, Amuchastegui S, Smiroldo S, Davalli AM \& Adorini L. Regulatory T cells induced by 1 alpha,25dihydroxyvitamin D3 and mycophenolate mofetil treatment mediate transplantation tolerance. Journal of Immunology $2001 \mathbf{1 6 7}$ 1945-1953. (https://doi.org/10.4049/jimmunol.167.4.1945)

55 Daniel C, Sartory NA, Zahn N, Radeke HH \& Stein JM. Immune modulatory treatment of trinitrobenzene sulfonic acid colitis with calcitriol is associated with a change of a T helper (Th) 1/Th17 to a Th2 and regulatory $\mathrm{T}$ cell profile. Journal of Pharmacology and Experimental Therapeutics 2008324 23-33. (https://doi.org/10.1124/ jpet.107.127209)

56 Sakaguchi S, Yamaguchi T, Nomura T \& Ono M. Regulatory T cells and immune tolerance. Cell 2008133 775-787. (https://doi. org/10.1016/j.cell.2008.05.009) 
57 Rudensky AY. Regulatory T cells and Foxp3. Immunological Reviews 2011241 260-268. (https://doi.org/10.1111/j.1600065X.2011.01018.x)

58 Laplana M, Royo JL \& Fibla J. Vitamin D Receptor polymorphisms and risk of enveloped virus infection: a meta-analysis. Gene $2018 \mathbf{6 7 8}$ 384-394. (https://doi.org/10.1016/j.gene.2018.08.017)

59 Iwasaki A \& Medzhitov R. Regulation of adaptive immunity by the innate immune system. Science 2010327 291-295. (https://doi. org/10.1126/science.1183021)

60 Hansdottir S, Monick MM, Hinde SL, Lovan N, Look DC \& Hunninghake GW. Respiratory epithelial cells convert inactive vitamin D to its active form: potential effects on host defense. Journal of Immunology 2008181 7090-7099. (https://doi.org/10.4049/ jimmunol.181.10.7090)

61 Reichel H, Koeffler HP, Barbers R \& Norman AW. Regulation of 1,25 dihydroxyvitamin D3 production by cultured alveolar macrophages from normal human donors and from patients with pulmonary sarcoidosis. Journal of Clinical Endocrinology and Metabolism 198765 1201-1209. (https://doi.org/10.1210/jcem-65-6-1201)

62 Liu PT, Stenger S, Li H, Wenzel L, Tan BH, Krutzik SR, Ochoa MT, Schauber J, Wu K, Meinken C et al. Toll-like receptor triggering of a vitamin D-mediated human antimicrobial response. Science 2006311 1770-1773. (https://doi.org/10.1126/science.1123933)

63 Fritsche J, Mondal K, Ehrnsperger A, Andreesen R \& Kreutz M. Regulation of 25 hydroxyvitamin D3-1 alpha-hydroxylase and production of 1 alpha,25-dihydroxyvitamin D3 by human dendritic cells. Blood 2003102 3314-3316. (https://doi.org/10.1182/blood2002-11-3521)

64 Hewison M, Freeman L, Hughes SV, Evans KN, Bland R, Eliopoulos AG, Kilby MD, Moss PA \& Chakraverty R. Differential regulation of vitamin $\mathrm{D}$ receptor and its ligand in human monocytederived dendritic cells. Journal of Immunology 2003170 5382-5390. (https://doi.org/10.4049/jimmunol.170.11.5382)

65 Sigmundsdottir H, Pan J, Debes GF, Alt C, Habtezion A, Soler D \& Butcher EC. DCs metabolize sunlight-induced vitamin D3 to 'program' T cell attraction to the epidermal chemokine CCL27. Nature Immunology 20078 285-293. (https://doi.org/10.1038/ni1433)

66 Guo XJ \& Thomas PG. New fronts emerge in the influenza cytokine storm. Seminars in Immunopathology 201739 541-550. (https://doi. org/10.1007/s00281-017-0636-y)

67 Aibana O, Huang CC, Aboud S, Arnedo-Pena A, Becerra MC, Bellido-Blasco JB, Bhosale R, Calderon R, Chiang S, Contreras C et al. Vitamin D status and risk of incident tuberculosis disease: a nested case-control study, systematic review, and individual-participant data meta-analysis. PLoS Medicine 201916 e1002907. (https://doi. org/10.1371/journal.pmed.1002907)

68 Watkins RR, Lemonovich TL \& Salata RA. An update on the association of vitamin D deficiency with common infectious diseases. Canadian Journal of Physiology and Pharmacology 201593 363-368. (https://doi.org/10.1139/cjpp-2014-0352)

69 Jassil NK, Sharma A, Bikle D \& Wang X. Vitamin D binding protein and 25-hydroxyvitmain D levels: emerging clinical applications. Endocrine Practice 201723 605-613. (https://doi.org/10.4158/ EP161604.RA)

70 Chun RF, Lauridsen AL, Suon L, Zella LA, Pike JW, Modlin RL, Martineau AR, Wilkinson RJ, Adams J \& Hewison M. Vitamin D-binding protein directs monocyte responses to 25 hydroxy-and 1,25-dihydroxyvitamin D. Journal of Clinical Endocrinology and Metabolism 201095 3368-3376. (https://doi.org/10.1210/jc.20100195)

71 Channappanavar R \& Perlman S. Pathogenic human coronavirus infections: causes and consequences of cytokine storm and immunopathology. Seminars in Immunopathology 201739 529-539. (https://doi.org/10.1007/s00281-017-0629-x)

72 Chu CM, Poon LL, Cheng VC, Chan KS, Hung IF, Wong MM, Chan KH, Leung WS, Tang BS, Chan VL et al. Initial viral load and the outcomes of SARS. Canadian Medical Association Journal 2004171 1349-1352. (https://doi.org/10.1503/cmaj.1040398)

73 Oh MD, Park WB, Choe PG, Choi SJ, Kim JI, Chae J, Park SS, Kim EC, Oh HS, Kim EJ et al. Viral load kinetics of MERS coronavirus infection. New England Journal of Medicine 2016375 1303-1305. (https://doi.org/10.1056/NEJMc1511695)

74 Kohlmeier JE, Cookenham T, Roberts AD, Miller SC \& Woodland DL. Type I interferons regulate cytolytic activity of memory CD8(+) T cells in the lung airways during respiratory virus challenge. Immunity 201033 96-105. (https://doi.org/10.1016/j. immuni.2010.06.016)

75 Channappanavar R, Fehr AR, Vijay R, Mack M, Zhao J, Meyerholz DK \& Perlman S. Dysregulated Type I interferon and inflammatory monocyte-macrophage responses cause lethal pneumonia in SARSCoV-infected mice. Cell Host and Microbe 201619 181-193. (https:// doi.org/10.1016/j.chom.2016.01.007)

76 Zhao J, Zhao J \& Perlman S. T cell responses are required for protection from clinical disease and for virus clearance in severe acute respiratory syndrome coronavirus-infected mice. Journal of Virology 201084 9318-9325. (https://doi.org/10.1128/JVI.01049-10)

77 Driggin E, Madhavan MV, Bikdeli B, Chuich T, Laracy J, BiondiZoccai G, Brown TS, Der, Der Nigoghossian C, Zidar DA, Haythe J et al. Cardiovascular considerations for patients, health care workers, and health systems during the coronavirus disease 2019 (COVID 19) pandemic. Journal of the American College of Cardiology 202075 2352-2371. (https://doi.org/10.1016/j.jacc.2020.03.031)

78 Clerkin KJ, Fried JA, Raikhelkar J, Sayer G, Griffin JM, Masoumi A, Jain SS, Burkhoff D, Kumaraiah D, Rabbani L et al. Coronavirus disease 2019 (COVID-19) and cardiovascular disease. Circulation 2020141 1648-1655. (https://doi.org/10.1161/ CIRCULATIONAHA.120.046941)

79 Bangalore S, Sharma A, Slotwiner A, Yatskar L, Harari R, Shah B, Ibrahim H, Friedman GH, Thompson C, Alviar CL et al. ST-segment elevation in patients with covid 19 - a case series. New England Journal of Medicine 2020382 2478-2480. (https://doi.org/10.1056/ NEJMc2009020)

80 Shi S, Qin M, Shen B, Cai Y, Liu T, Yang F, Gong W, Liu X, Liang J, Zhao Q et al. Association of cardiac injury with mortality in hospitalized patients with COVID-19 in Wuhan, China. JAMA Cardiology 20205 802-810. (https://doi.org/10.1001/ jamacardio.2020.0950)

81 Guo T, Fan Y, Chen M, Wu X, Zhang L, He T, Wang H, Wan J, Wang $\mathrm{X} \& \mathrm{Lu}$ Z. Cardiovascular implications of fatal outcomes of patients with coronavirus disease 2019 (COVID-19). JAMA Cardiology 20205 1-8. (https://doi.org/10.1001/jamacardio.2020.1017)

82 Arentz M, Yim E, Klaff L, Lokhandwala S, Riedo FX, Chong M \& Lee M. Characteristics and outcomes of 21 critically ill patients With COVID-19 in Washington State. JAMA 2020323 1612-1614. (https:// doi.org/10.1001/jama.2020.4326)

83 Ruan Q, Yang K, Wang W, Jiang L \& Song J. Clinical predictors of mortality due to COVID-19 based on an analysis of data of 150 patients from Wuhan, China. Intensive Care Medicine 202046 846-848. (https://doi.org/10.1007/s00134-020-05991-x)

84 Kochav SM, Coromilas E, Nalbandian A, Ranard LS, Gupta A, Chung MK, Gopinathannair R, Biviano AB, Garan H \& Wan EY. Cardiac arrhythmias in COVID-19 infection. Circulation: Arrhythmia and Electrophysiology 202013 e008719. (https://doi.org/10.1161/ CIRCEP.120.008719)

85 Wang D, Hu B, Hu C, Zhu F, Liu X, Zhang J, Wang B, Xiang H, Cheng Z, Xiong Y et al. Clinical characteristics of 138 hospitalized patients with 2019 novel coronavirus-infected pneumonia in Wuhan, China. JAMA 2020323 1061-1069. (https://doi.org/10.1001/ jama.2020.1585)

86 Oh J, Weng S, Felton SK, Bhandare S, Riek A, Butler B, Proctor BM, Petty M, Chen Z, Schechtman KB et al. 1,25(OH)2 vitamin D inhibits foam cell formation and suppresses macrophage cholesterol uptake 
in patients with type 2 diabetes mellitus. Circulation $2009 \mathbf{1 2 0}$ 687-698. (https://doi.org/10.1161/CIRCULATIONAHA.109.856070)

87 Yin K, You Y, Swier V, Tang L, Radwan MM, Pandya AN \& Agrawal DK. Vitamin D protects against atherosclerosis via regulation of cholesterol efflux and macrophage polarization in hypercholesterolemic swine. Arteriosclerosis, Thrombosis, and Vascular Biology 201535 2432-2442. (https://doi.org/10.1161/ ATVBAHA.115.306132)

88 Norman PE \& Powell JT. Vitamin D and cardiovascular disease. Circulation Research 2014114 379-393. (https://doi.org/10.1161/ CIRCRESAHA.113.301241)

89 Christakos S, Dhawan P, Verstuyf A, Verlinden L \& Carmeliet G. Vitamin D: metabolism, molecular mechanism of action, and pleiotropic effects. Physiological Reviews 201696 365-408. (https:// doi.org/10.1152/physrev.00014.2015)

90 Pilz S, Verheyen N, Grübler MR, Tomaschitz A \& März W. Vitamin $\mathrm{D}$ and cardiovascular disease prevention. Nature Reviews: Cardiology 201613 404-417. (https://doi.org/10.1038/nrcardio.2016.73)

91 Bouillon R, Carmeliet G, Verlinden L, van Etten E, Verstuyf A, Luderer HF, Lieben L, Mathieu C \& Demay M. Vitamin D and human health: lessons from vitamin D receptor null mice. Endocrine Reviews 200829 726-776. (https://doi.org/10.1210/er.2008-0004)

92 Maddaloni E \& Buzzetti R. Covid-19 and diabetes mellitus: unveiling the interaction of two pandemics. Diabetes/Metabolism Research and Reviews 2020 e33213321 In press. (https://doi.org/10.1002/dmrr.3321)

93 Dietz W \& Santos-Burgoa C. Obesity and its implications for COVID-19 mortality. Obesity 202028 1005. (https://doi.org/10.1002/ oby.22818)

94 Lighter J, Phillips M, Hochman S, Sterling S, Johnson D, Francois F \& Stachel A. Obesity in patients younger than 60 years is a risk factor for Covid-19 hospital admission. Clinical Infectious Diseases 202071 896-897. (https://doi.org/10.1093/cid/ciaa415)

95 Simonnet A, Chetboun M, Poissy J, Raverdy V, Noulette J, Duhamel A, Labreuche J, Mathieu D, Pattou F, Jourdain M et al. High prevalence of obesity in severe acute respiratory syndrome coronavirus-2 (SARS-CoV-2) requiring invasive mechanical ventilation. Obesity 202028 1195-1199. (https://doi.org/10.1002/ oby.22831)

96 Fang L, Karakiulakis G \& Roth M. Are patients with hypertension and diabetes mellitus at increased risk for COVID-19 infection? Lancet: Respiratory Medicine 20208 e21. (https://doi.org/10.1016/S22132600(20)30116-8)

97 Chow N, Fleming-Dutra K, Gierke R, Hall A, Hughes M, Pilishvili T, Ritchey M, Roguski K, Skoff T \& Ussery E. Preliminary estimates of the prevalence of selected underlying health conditions among patients with coronavirus disease 2019 - United States February 12March 28, 2020. MMWR: Morbidity and Mortality Weekly Report 2020 69386.

98 Cheng Y, Luo R, Wang K, Zhang M, Wang Z, Dong L, Li J, Yao Y, Ge $S \&$ Xu G. Kidney disease is associated with in-hospital death of patients with COVID-19. Kidney International 202097 829-838. (https://doi.org/10.1016/j.kint.2020.03.005)

99 Kunutsor SK, Apekey TA \& Steur M. Vitamin D and Risk of Future Hypertension: Meta Analysis of 283,537 Participants. Springer, 2013.

100 Song Y, Wang L, Pittas AG,Del Gobbo LC, Zhang C, Manson JE $\&$ Hu FB. Blood 25 hydroxy vitamin D levels and incident type 2 diabetes: a meta-analysis of prospective studies. Diabetes Care 2013 36 1422-1428. (https://doi.org/10.2337/dc12-0962)

101 Pereira-Santos M, Costa PR, Assis AM, Santos CA \& Santos DB. Obesity and vitamin D deficiency: a systematic review and metaanalysis. Obesity Reviews 201516 341-349. (https://doi.org/10.1111/ obr.12239)

102 Dusso AS \& Tokumoto M. Defective renal maintenance of the vitamin D endocrine system impairs vitamin D renoprotection: a downward spiral in kidney disease. Kidney International 201179 715-729. (https://doi.org/10.1038/ki.2010.543)
103 Yuan W, Pan W, Kong J, Zheng W, Szeto FL, Wong KE, Cohen R, Klopot A, Zhang Z \& Li YC. 1,25-Dihydroxyvitamin D3 suppresses renin gene transcription by blocking the activity of the cyclic AMP response element in the renin gene promoter. Journal of Biological Chemistry 2007282 29821-29830. (https://doi.org/10.1074/jbc. M705495200)

$104 \mathrm{Li}$ YC. Molecular mechanism of vitamin D in the cardiovascular system. Journal of Investigative Medicine 201159 868-871. (https:// doi.org/10.2310/JIM.0b013e31820ee448)

105 Chen S, Sun Y \& Agrawal DK. Vitamin D deficiency and essential hypertension. Journal of the American Society of Hypertension 20159 885-901. (https://doi.org/10.1016/j.jash.2015.08.009)

$106 \mathrm{Ni} \mathrm{W}$, Watts SW, Ng M, Chen S, Glenn DJ \& Gardner DG. Elimination of vitamin D receptor in vascular endothelial cells alters vascular function. Hypertension 201464 1290-1298. (https://doi. org/10.1161/HYPERTENSIONAHA.114.03971)

107 Ye M, Wysocki J, William J, Soler MJ, Cokic I \& Batlle D. Glomerular localization and expression of angiotensin-converting enzyme 2 and angiotensin-converting enzyme: implications for albuminuria in diabetes. Journal of the American Society of Nephrology $2006 \mathbf{1 7}$ 3067-3075. (https://doi.org/10.1681/ASN.2006050423)

108 Kuba K, Imai Y, Ohto-Nakanishi T \& Penninger JM. Trilogy of ACE2: a peptidase in the renin-angiotensin system, a SARS receptor, and a partner for amino acid transporters. Pharmacology and Therapeutics 2010128 119-128. (https://doi.org/10.1016/j. pharmthera.2010.06.003)

109 Strawn WB, Ferrario CM \& Tallant EA. Angiotensin-(1-7) reduces smooth muscle growth after vascular injury. Hypertension 199933 207-211. (https://doi.org/10.1161/01.hyp.33.1.207)

110 Pilz S, Tomaschitz A, Drechsler C, Dekker JM \& März W. Vitamin D deficiency and myocardial diseases. Molecular Nutrition and Food Research 201054 1103-1113. (https://doi.org/10.1002/ mnfr.200900474)

111 Wang L, Song Y, Manson JE, Pilz S, März W, Michaëlsson K, Lundqvist A, Jassal SK, Barrett-Connor E, Zhang C et al. Circulating 25-hydroxy-vitamin D and risk of cardiovascular disease: a meta-analysis of prospective studies. Circulation: Cardiovascular Quality and Outcomes 20125 819-829. (https://doi.org/10.1161/ CIRCOUTCOMES.112.967604)

112 Brøndum-Jacobsen P, Benn M, Jensen GB \& Nordestgaard BG. 25-Hydroxyvitamin D levels and risk of ischemic heart disease, myocardial infarction, and early death: population based study and meta-analyses of 18 and 17 studies. Arteriosclerosis, Thrombosis, and Vascular Biology 201232 2794-2802. (https://doi.org/10.1161/ ATVBAHA.112.248039)

113 Sokol SI, Tsang P, Aggarwal V, Melamed ML \& Srinivas VS. Vitamin D status and risk of cardiovascular events: lessons learned via systematic review and meta-analysis. Cardiology in Review 201119 192-201. (https://doi.org/10.1097/CRD.0b013e31821da9a5)

114 Pittas AG, Chung M, Trikalinos T, Mitri J, Brendel M, Patel K, Lichtenstein AH, Lau J \& Balk EM. Systematic review: vitamin D and cardiometabolic outcomes. Annals of Internal Medicine 2010152 307-314. (https://doi.org/10.7326/0003-4819-152-5-20100302000009)

115 Theodoratou E, Tzoulaki I, Zgaga L \& Ioannidis JP. Vitamin D and multiple health outcomes: umbrella review of systematic reviews and meta-analyses of observational studies and randomised trials. BMJ 2014348 g2035. (https://doi.org/10.1136/bmj.g2035)

116 Tomson J, Emberson J, Hill M, Gordon A, Armitage J, Shipley M, Collins R \& Clarke R. Vitamin D and risk of death from vascular and non-vascular causes in the Whitehall study and meta-analyses of 12 000 deaths. European Heart Journal 201334 1365-1374. (https://doi. org/10.1093/eurheartj/ehs426)

117 Witte KK, Byrom R, Gierula J, Paton MF, Jamil HA, Lowry JE, Gillott RG, Barnes SA, Chumun H, Kearney LC et al. Effects of vitamin $\mathrm{D}$ on cardiac function in patients with chronic HF: the 
VINDICATE study. Journal of the American College of Cardiology 2016 67 2593-2603. (https://doi.org/10.1016/j.jacc.2016.03.508)

118 Bikdeli B, Madhavan MV, Jimenez D, Chuich T, Dreyfus I, Driggin E, Nigoghossian C, Ageno W, Madjid M, Guo Y et al. COVID-19 and thrombotic or thromboembolic disease: implications for prevention, antithrombotic therapy, and follow up. Journal of the American College of Cardiology 202075 2950-2973. (https://doi.org/10.1016/j. jacc.2020.04.031)

119 Klok FA, Kruip MJHA, van der Meer NJM, Arbous MS, Gommers DAMPJ, Kant KM, Kaptein FHJ, van Paassen J, Stals MAM, Huisman MV et al. Incidence of thrombotic complications in critically ill ICU patients with COVID-19. Thrombosis Research 2020 191 145-147. (https://doi.org/10.1016/j.thromres.2020.04.013)

120 Tang N, Bai H, Chen X, Gong J, Li D \& Sun Z. Anticoagulant treatment is associated with decreased mortality in severe coronavirus disease 2019 patients with coagulopathy. Journal of Thrombosis and Haemostasis 202018 1094-1099. (https://doi. org/10.1111/jth.14817)

121 Tang N, Li D, Wang X \& Sun Z. Abnormal coagulation parameters are associated with poor prognosis in patients with novel coronavirus pneumonia. Journal of Thrombosis and Haemostasis 202018 844-847. (https://doi.org/10.1111/jth.14768)

122 Poissy J, Goutay J, Caplan M, Parmentier E, Duburcq T, Lassalle F, Jeanpierre E, Rauch A, Labreuche J, Susen S et al. Pulmonary embolism in COVID-19 patients: awareness of an increased prevalence. Circulation 2020142 184-186. (https://doi.org/10.1161/ CIRCULATIONAHA.120.047430)

123 Mao L, Jin H, Wang M, Hu Y, Chen S, He Q, Chang J, Hong C, Zhou Y, Wang D et al. Neurologic manifestations of hospitalized patients with coronavirus disease 2019 in Wuhan, China. JAMA Neurology 202077 1-9. (https://doi.org/10.1001/ jamaneurol.2020.1127)

124 Aihara K, Azuma H, Akaike M, Ikeda Y, Yamashita M, Sudo T, Hayashi H, Yamada Y, Endoh F, Fujimura M et al. Disruption of nuclear vitamin D receptor gene causes enhanced thrombogenicity in mice. Journal of Biological Chemistry 2004279 35798-35802. (https://doi.org/10.1074/jbc.M404865200)

125 Mohammad S, Mishra A \& Ashraf MZ. Emerging role of vitamin D and its associated molecules in pathways related to pathogenesis of thrombosis. Biomolecules 20199 649. (https://doi.org/10.3390/ biom9110649)

126 Entezari-Maleki T, Talasaz AH, Salarifar M, Hadiibabaie M, Javadi MR, Bozorgi A, Jenab Y, Boroumand MA \& Gholami K. Plasma vitamin D status and its correlation with risk factors of thrombosis, P-selectin and hs-CRP level in patients with venous thromboembolism; the first Study of Iranian Population. Iranian Journal of Pharmaceutical Research 201413 319-327.

$127 \mathrm{Wu}$ WX \& He DR. Low vitamin D levels are associated With the development of deep venous thromboembolic events in patients With ischemic stroke. Clinical and Applied Thrombosis/Hemostasis 201824 69S-75S. (https://doi.org/10.1177/1076029618786574)

128 Khademvatani K, Seyyed-Mohammadzad MH, Akbari M, Rezaei Y, Eskandari R \& Rostamzadeh A. The relationship between vitamin $\mathrm{D}$ status and idiopathic lower-extremity deep vein thrombosis. International Journal of General Medicine 20147 303-309. (https://doi. org/10.2147/IJGM.S64812)

129 Amrein K, Schnedl C, Berghold A, Pieber TR \& Dobnig H. Correction of vitamin D deficiency in critically ill patients - VITdAL@ICU study protocol of a double-blind, placebo controlled randomized clinical trial. BMC Endocrine Disorders 201212 27. (https://doi. org/10.1186/1472-6823-12-27)

130 Azim A, Ahmed A, Yadav S, Baronia AK, Gurjar M, Godbole MM, Poddar B \& Singh RK. Prevalence of vitamin D deficiency in critically ill patients and its influence on outcome experience from a tertiary care centre in North India (an observational study). Journal of Intensive Care 20131 14. (https://doi.org/10.1186/2052-0492-1-14)
131 Amrein K, Schnedl C, Holl A, Riedl R, Christopher KB, Pachler C, Purkart TU, Waltensdorfer A, Munch A, Warnkross $\mathrm{H}$ et al. Effect of high-dose vitamin D3 on hospital length of stay in critically ill patients with vitamin D deficiency: the VITdAL-ICU randomized clinical trial. JAMA 2014312 1520-1530. (https://doi.org/10.1001/jama.2014.13204)

132 Krzysztof S. The sun in Hindu scriptures. In Suryanamaskar: Sun Salutations, pp. 21-26. New Delhi: Motilal Banarsidass Publishers Private Ltda, 2020.

133 McCullough PJ \& Lehrer DS. Vitamin D, cod liver oil, sunshine, and phototherapy: safe, effective and forgotten tools for treating and curing tuberculosis infections - a comprehensive review. Journal of Steroid Biochemistry and Molecular Biology 2018177 21-29. (https:// doi.org/10.1016/j.jsbmb.2017.07.027)

134 Bouillon R, Marcocci C, Carmeliet G, Bikle D, White JH, DawsonHughes B, Lips P, Munns CF, Lazaretti-Castro M, Giustina A et al. Skeletal and extraskeletal actions of vitamin D: current evidence and outstanding questions. Endocrine Reviews 201940 1109-1151. (https://doi.org/10.1210/er.2018-00126)

135 Sharma OP. Hypercalcemia in granulomatous disorders: a clinical review. Current Opinion in Pulmonary Medicine 20006 442-447. (https://doi.org/10.1097/00063198-200009000-00010)

136 Jingyan X, Liyun S, Lifang Z \& Xu F. Impact of vitamin D supplementation on the outcome of tuberculosis treatment: a systematic review and metaanalysis of randomized controlled trials. Chinese Medical Journal 2014127 3127-3134.

137 Wu HX, Xiong XF, Zhu M, Wei J, Zhuo KQ \& Cheng DY. Effects of vitamin D supplementation on the outcomes of patients with pulmonary tuberculosis: a systematic review and meta-analysis. $B M C$ Pulmonary Medicine 201818 108. (https://doi.org/10.1186/s12890018-0677-6)

138 Cannell JJ, Vieth R, Umhau JC, Holick MF, Grant WB, Madronich S, Garland CF \& Giovannucci E. Epidemic influenza and vitamin D. Epidemiology and Infection 2006134 1129-1140. (https://doi. org/10.1017/S0950268806007175)

139 Mathyssen C, Gayan-Ramirez G, Bouillon R \& Janssens W. Vitamin D supplementation in respiratory diseases: evidence from randomized controlled trials. Polish Archives of Internal Medicine 2017127 775-784. (https://doi.org/10.20452/pamw.4134)

140 Sabetta JR, DePetrillo P, Cipriani RJ, Smardin J, Burns LA \& Landry ML. Serum 25 hydroxyvitamin D and the incidence of acute viral respiratory tract infections in healthy adults. PLOS ONE 20105 e11088. (https://doi.org/10.1371/journal.pone.0011088)

141 Science M, Maguire JL, Russell ML, Smieja M, Walter SD \& Loeb M. Low serum 25 hydroxyvitamin D level and risk of upper respiratory tract infection in children and adolescents. Clinical Infectious Diseases 201357 392-397. (https://doi.org/10.1093/cid/cit289)

142 Dancer RC, Parekh D, Lax S, D'Souza V, Zheng S, Bassford CR, Park D, Bartis DG, Mahida R, Turner AM et al. Vitamin D deficiency contributes directly to the acute respiratory distress syndrome (ARDS). Thorax 201570 617-624. (https://doi.org/10.1136/ thoraxjnl-2014-206680)

143 Monlezun DJ, Bittner EA, Christopher KB, Camargo CA \& Quraishi SA. Vitamin D status and acute respiratory infection: cross sectional results from the United States National/Health and Nutrition Examination Survey, 2001-2006. Nutrients 20157 1933-1944. (https://doi.org/10.3390/nu7031933)

144 Martineau AR, Jolliffe DA, Greenberg L, Aloia JF, Bergman P, DubnovRaz G, Esposito S, Ganmaa D, Ginde AA, Goodall EC et al. Vitamin D supplementation to prevent acute respiratory infections: individual participant data meta-analysis. Health Technology Assessment 201923 1-44. (https://doi.org/10.3310/hta23020)

145 Lau FH, Majumder R, Torabi R, Saeg F, Hoffman R, Cirillo JD \& Greiffenstein P. Vitamin D insufficiency is prevalent in severe COVID19. medRxiv 2020. (https://doi.org/101101/2020.04.24.20075838)

146 Lanham-New SA, Webb AR, Cashman KD, Buttris JL, Fallowfield JL, Msud T, Hewison M et al. Vitamin D and SARS-CoV-2 vurus/COVID- 
019 disease. BMJ Nutrition, Prevention and Health 20203 106-110. (https://doi.org/10.1136/bmjnph-2020-000089)

147 Daneshkhah A, Agrawal V, Eshein A et al. The possible role of vitamin D in suppressing cytokine storm and associated mortality in COVID-19 patients medRxiv 2020. 2020.2004.2008.20058578.

148 Ilie PC, Stefanescu S \& Smith L. The role of vitamin D in the prevention of coronavirus disease 2019 infection and mortality. Aging Clinical and Experimental Research 202032 1195-1198. (https:// doi.org/10.1007/s40520-020-01570-8)

149 Marik PE, Kory P \& Varon J. Does vitamin D status impact mortality from SARS-CoV-2 infection? Medicine in Drug Discovery 20206 100041. (https://doi.org/10.1016/j.medidd.2020.100041)

150 Gennari L, Campi I, Merlotti D, Mingiano C, Frosali A, Giovanelli L, Torlasco C, Pengo M, Heilbron F, Davide S et al. Vitamin D deficiency is independently associated with COVID-19 severity and mortality. ASBMR Annual Meeting, 2020.

151 D'Avolio A, Avataneo V, Manca A, Cusato J, De Nicolò A, Lucchini R, Keller F \& Cantù M. 25-Hydroxyvitamin D concentrations are lower in patients with positive PCR for SARS CoV-2. Nutrients 202012 E1359. (https://doi.org/10.3390/nu12051359)

152 Hastie CE, Mackay DF, Ho F, Celis-Morales CA, Katikireddi SV, Niedzwiedz CL, Jani BD, Welsh P, Mair FS, Gray SR et al. Vitamin D concentrations and COVID-19 infection in UK Biobank. Diabetology and Metabolic Syndrome 202014 561-565. (https://doi.org/10.1016/j. dsx.2020.04.050)

153 Grant WB, Lahore H, McDonnell SL, Baggerly CA, French CB, Aliano JL \& Bhattoa HP. Evidence that vitamin D supplementation could reduce risk of influenza and COVID-19 infections and deaths. Nutrients 202012 988. (https://doi.org/10.3390/nu12040988)

154 Isaia G, Giorgino R, Rini GB, Bevilacqua M, Maugeri D \& Adami S. Prevalence of hypovitaminosis D in elderly women in Italy: clinical consequences and risk factors. Osteoporosis International 200314 577-582. (https://doi.org/10.1007/s00198-003-1390-7)

155 Romagnoli E, Caravella P, Scarnecchia L, Martinez P \& Minisola S. Hypovitaminosis D in an Italian population of healthy subjects and hospitalized patients.British Journal of Nutrition 199981 133-137. (https://doi.org/10.1017/S0007114599000264)

156 Formenti AM, Tecilazich F, Frara S, Giubbini R, De Luca H \& Giustina A. Body mass index predicts resistance to active vitamin D in patients with hypoparathyroidism. Endocrine 201966 699-700. (https://doi.org/10.1007/s12020-019-02105-6)

157 Boccardi V, Lapenna M, Gaggi L, Garaffa FM, Croce MF, Baroni M, Ercolani S, Mecocci P \& Ruggiero C. Hypovitaminosis D: a disease marker in hospitalized very old persons at risk of malnutrition. Nutrients 201911 128. (https://doi.org/10.3390/nu11010128)

158 Degli Esposti L, Girardi A, Saragoni S, Sella S, Andretta M, Rossini M, Giannini S \& on the behalf of the Study Group. Use of antiosteoporotic drugs and calcium/vitamin D in patients with fragility fractures: impact on re-fracture and mortality risk. Endocrine 201964 367-377. (https://doi.org/10.1007/s12020-018-1824-9)

159 Gupta R, Hussain A \& Misra A. Diabetes and COVID-19: evidence, current status and unanswered research questions. European Journal of Clinical Nutrition 202074 864-870. (https://doi.org/10.1038/s41430020-0652-1)

160 Zheng Z, Peng F, Xu B, Zhao J, Liu H, Peng J, Li Q, Jiang C, Zhou Y, Liu S et al. Risk factors of critical and mortal COVID-19 cases: a systematic literature review and meta analysis. Journal of Infection 202081 e16-e25. (https://doi.org/10.1016/j.jinf.2020.04.021)

161 Gupta A, Madhavan MV, Sehgal K, Nair N, Mahajan S, Sehrawat TS, Bikdeli B, Ahluwalia N, Ausiello JC, Wan EY et al. Extrapulmonary manifestations of COVID-19. Nature Medicine 202026 1017-1032. (https://doi.org/10.1038/s41591-020-0968-3)

Received 15 June 2020

Revised version received 27 July 2020

Accepted 4 August 2020 